\title{
Predatory impact of the freshwater invader Dikerogammarus villosus (Crustacea: Amphipoda)
}

\author{
J aimie T.A. Dick, Dirk Platvoet, and David W. Kelly
}

\begin{abstract}
To assess the increasing threats to aquatic ecosystems from invasive species, we need to elucidate the mechanisms of impacts of current and predicted future invaders. Dikerogammarus villosus, a Ponto-Caspian amphipod crustacean, is invading throughout Europe and predicted to invade the North American Great Lakes. European field studies show that populations of macroinvertebrates decline after $D$. villosus invasion. The mechanism of such impacts has not been addressed empirically; however, D. villosus is known to prey upon and replace other amphipods. Therefore, in this study, we used microcosm and mesocosm laboratory experiments, with both single and mixed prey species scenarios, to assess any predatory impact of $D$. villosus on a range of macroinvertebrate taxa, trophic groups, and body sizes. Dikerogammarus villosus predatory behaviour included shredding of prey and infliction of "bite" injuries on multiple victims. Dikerogammarus villosus killed significantly greater numbers of macroinvertebrates than did the native Gammarus duebeni, which is currently being replaced by D. villosus. This invader thus appears to impact on freshwater ecosystems through its exceptional predatory capabilities. We predict that future invasions by $D$. villosus will have serious direct and indirect effects on freshwaters, with its invasion facilitated in a larger "invasional meltdown" in regions like the North American Great Lakes.
\end{abstract}

Résumé : Pour évaluer la menace grandissante que représentent les espèces envahissantes pour les écosystèmes aquatiques, il est nécessaire d'élucider les mécanismes par lesquels les envahisseurs actuels et ceux qu'on prévoit dans le futur causent leur impact. Dikerogammarus villosus, un crustacé amphipode originaire de la région pontocaspienne, est en train d'envahir l'Europe et on prédit qu'il se retrouvera éventuellement dans les Grands-Lacs nord-américains. Des études sur le terrain en Europe révèlent que les populations de macroinvertébrés diminuent après une invasion de $D$. villosus. Le mécanisme qui cause un tel impact n'a pas été étudié de façon empirique, mais il est connu que $D$. villosus se nourrit d'autres amphipodes et peut les remplacer. Des expériences en laboratoire en microcosmes et en mésocosmes avec des scénarios pour une seule ou plusieurs espèces de proies nous ont permis d'évaluer l'impact de D. villosus en tant que prédateur d'une gamme de macroinvertébrés de taxons, de groupes trophiques et de tailles différents. Le comportement prédateur de D. villosus inclut le déchiquetage des proies et la morsure vulnérante de victimes multiples. Dikerogammarus villosus tue un nombre significativement plus grand de proies que ne le fait l'espèce indigène Gammarus duebeni qu'il est en voie de remplacer. L'envahisseur semble donc avoir un impact sur les écosystèmes d'eau douce à cause de ses capacités exceptionnelles de prédateur. On peut donc prédire que les invasions futures de $D$. villosus auront des effets importants, tant directs qu'indirects, sur les milieux d'eau douce et que son invasion sera facilitée par l'effondrement des communautés causé par les invasions dans des régions telles que les Grands-Lacs nord-américains.

[Traduit par la Rédaction]

\section{Introduction}

Invading aquatic species will continue to cause extensive ecological damage and economic loss (Hall and Mills 2000; Mack et al. 2000; Ricciardi and MacIsaac 2000), with invaders predicted to be the major drivers of changes in freshwater biodiversity over the next 100 years (Sala et al. 2000).

Received 1 March 2002. Accepted 23 May 2002. Published on the NRC Research Press Web site at http://cjfas.nrc.ca on 26 July 2002.

J16786

J.T.A. Dick ${ }^{1}$ and D.W. Kelly. School of Biology and Biochemistry, Queen's University Belfast, MBC, 97 Lisburn Road, Belfast BT9 7BL, Northern Ireland, U.K.

D. Platvoet. Zoological Museum of Amsterdam, and Institute for Biodiversity and Ecosystem Dynamics, Faculty of Science, University of Amsterdam, P.O. Box 94766, 1090 GT, Amsterdam, The Netherlands.

${ }^{1}$ Corresponding author (e-mail: j.dick@qub.ac.uk).
Indeed, the rate of aquatic invasions may be generally increasing, with systems like the North American Great Lakes threatened with "invasional meltdown" (Ricciardi 2001). Hence, current research priorities are identification of potential new invaders together with explanations and predictions of their mode and degree of impact (Ricciardi and Rasmussen 1998; Ricciardi 2001). The Ponto-Caspian amphipod crustacean Dikerogammarus villosus is currently invading throughout Europe (Dick and Platvoet 2000; van der Velde et al. 2000) and is predicted to invade the North American Great Lakes (Ricciardi and Rasmussen 1998). Field surveys indicate that the ecological impact of $D$. villosus invasions may be severe, with documented declines in macroinvertebrate species coincidental with the arrival of $D$. villosus in the Dutch Lower River Rhine (van der Velde et al. 2000; G. van der Velde and M. van Riel, Laboratory of Aquatic Ecology, University of Nijmegen, The Netherlands, personal communication), the Dutch IJssel Lake (Dick and Platvoet 2000), and the French Rivers Moselle, Saone, Rhone, and the Alsace Canal (Devin et al. 2001; L. Bollache and F. Cézilly, 
Table 1. Analysis of variance results for mean survival of prey in microcosm and mesocosm experiments (see Figs. 1 and 3 ).

\begin{tabular}{|c|c|c|c|c|}
\hline \multirow[b]{2}{*}{ Invertebrate prey } & \multicolumn{3}{|l|}{ Microcosms } & \multirow{2}{*}{$\begin{array}{l}\text { Mesocosms } \\
\text { Amphipod status } \\
\text { (none; Gd; Dv) } F_{2,27}\end{array}$} \\
\hline & $\begin{array}{l}\text { Amphipod status } \\
\text { (none; Gd; Dv) } F_{2,12}\end{array}$ & $\begin{array}{l}\text { Time (Days } 1,2,3 \text { ) } \\
F_{2,24}\end{array}$ & $\begin{array}{l}\text { Interaction } \\
F_{4,24} \\
\end{array}$ & \\
\hline (a) Caenis robusta & $86.6 * * * *$ & $11.3 * * *$ & $2.9 *$ & $13.2 * * * *$ \\
\hline (b) Asellus aquaticus & $14.8 * * *$ & $17.9 * * * *$ & $5.6 * *$ & $51.4 * * * *$ \\
\hline (c) Ischnura elegans (small) & $60.6 * * * *$ & $7.9 * *$ & 2.2 & $18.6 * * * *$ \\
\hline (d) Neomysis integer (large) & $6.7 * *$ & $5.3^{* *}$ & $5.3^{* *}$ & 0.54 \\
\hline (e) Ischnura elegans (large) & $45.9 * * * *$ & $10.6^{* * *}$ & $10.6 * * * *$ & $13.7 * * * *$ \\
\hline (f) Piscicola geometra & $10.8 * *$ & $4.1^{*}$ & $4.1 *$ & 0.49 \\
\hline (g) Sigara sp. & $11.3 * *$ & $15.2 * * * *$ & 1.6 & $3.6^{*}$ \\
\hline (h) Eurycercus lamellatus & $23.1 * * * *$ & $27.9 * * * *$ & $8.9 * * * *$ & 1.6 \\
\hline (i) Chironomus sp. & $273.9 * * * *$ & $16.1 * * * *$ & $5.1 * *$ & N/A \\
\hline (j) Neomysis integer (small) & $3.9 *$ & $17.1 * * * *$ & $2.6^{*}$ & 0.06 \\
\hline (k) Chaoborus sp. & $16.8 * * *$ & $50.5 * * * *$ & $3.2 *$ & 0.26 \\
\hline
\end{tabular}

Note: Gd, Gammarus duebeni; Dv, Dikerogammarus villosus. $* P<0.05$, $* * P<0.01$, *** $P<0.001$, $* * * *<0.0001$.

Laboratoire Ecologie - Evolution, Université de Bourgogne, Dijon, France, personal communication). The mechanism by which $D$. villosus impacts on macroinvertebrates has not been explicitly addressed; however, D. villosus has been shown to prey upon and replace populations of other amphipods, such as the North American Gammarus tigrinus (invasive in Europe) and a European native, Gammarus duebeni (Dick and Platvoet 2000). Hence, in the present study, laboratory experiments were designed to examine any predatory impact of $D$. villosus, in comparison to that of a native counterpart $(G$. duebeni), on a range of macroinvertebrate taxa and functional groups, in an attempt to elucidate the current and potential future impacts of this invader in fresh waters.

Recent studies have emphasized the utility of examining proximate behavioural mechanisms that may explain invasion success in terms of impacts on native species (see Holway and Suarez 1999). While extrapolations to the field from microcosm and mesocosm scale studies are much debated (see Huston 1999), studies of behavioural mechanisms elucidated from small-scale experiments have been successful in explaining and predicting community patterns in the field (Holway and Suarez 1999; Wilhelm and Schindler 1999; Wilhelm et al. 2000). In addition, studies carried out at multiple spatial scales improve extrapolations from individual behaviour to population and community scales (Peckarsky et al. 1997). Therefore, in this study, we conducted laboratory experiments at two spatial scales to assess any predatory impact of $D$. villosus on a suite of potential macroinvertebrate prey species. In addition, since absolute rates of predation may be inflated under laboratory conditions, we took a comparative approach, assessing $D$. villosus predation relative to that of a native counterpart, $G$. duebeni. First, we staged interactions between single amphipods and multiple individuals of each prey species at the microcosm scale. Second, we assessed changes in experimental communities of multiple amphipod individuals and multiple prey species at the mesocosm scale.

\section{Materials and methods}

Experiments 1 and 2 were conducted in July-August 2000 and 2001, respectively, at the University of Amsterdam. In both years, we collected $D$. villosus and $G$. duebeni from our previous study sites around the IJsselmeer and Markermeer (see Dick and Platvoet 2000). The amphipod species were housed separately with flora, fauna, and debris from their respective collection sites and used in experimental replicates the day following capture. In both experiments, we chose to use an abundant size class of adult males of the two species. Although D. villosus is on average larger than $G$. duebeni (Dick and Platvoet 2000), we used matching sizes of males in the range 16-22 mm body length, thus examining any species effect rather than any confounding size effect. If, however, as is likely, predation is size dependent, any differences in predation frequencies between the two amphipod species in the present experiments will be conservative estimates. This choice of sex and size class was also a compromise between the largest males, which may have overestimated predatory impacts, and smaller males and females, which may have underestimated predatory impacts. Macroinvertebrates were collected from freshwater sites that were as of yet not invaded by D. villosus; namely, the location known as "Gaslocatie N.A.M.", near Middelie, North Holland, and "Broek in Waterland", north of Amsterdam. Together, these sites provided macroinvertebrates representing typical freshwater taxonomic groups, principally, insects (nymphs and (or) larvae) and crustaceans (see Table 1 and Fig. 1). Trophic or Functional Feeding Groups (sensu Cummins and Klug 1979) were widely represented and there was a large size range of potential prey, both soft and hard bodied (see Fig. 1).

In Experiment 1, aquaria of $20 \times 20 \times 10 \mathrm{~cm}(\mathrm{~L} \times \mathrm{W} \times \mathrm{H})$ were supplied with $3.5 \mathrm{~L}$ of aerated water, which was a mixture from the collection sites detailed above $\left(17-18^{\circ} \mathrm{C}\right.$; conductivity, 800-900 $\left.\mu \mathrm{S} \cdot \mathrm{cm}^{-1}\right)$. Broken terracotta plant pots provided a diversity of three-dimensional heterogeneous surfaces and crevices for predator and prey to use. Field densities of amphipods range from less than one up to several thousand per square metre (e.g., Welton 1979; Musko 1993), with our study sites showing similar variation. In the present study, amphipods were interacting in aquaria at a density equivalent to $25 \cdot \mathrm{m}^{-2}$, at the lower end of field densities. Macroinvertebrates were introduced into microcosms and allowed to settle for $2 \mathrm{~h}$ before amphipods were introduced. For each of 11 macroinvertebrate prey (see Fig. 1), five replicates each containing five individuals were monitored for three days in each of three experimental groups: $(i)$ no am- 
Fig. 1. Mean (+ standard error) survival of macroinvertebrates over three days in the microcosm (single prey species) experiments, with no amphipod present (open bars), Gammarus duebeni present (hatched bars), and Dikerogammarus villosus present (cross-hatched bars). Plots $a-k$ are arranged from greatest to least difference in survival of macroinvertebrates at day 3 in microcosms with invader compared to native. Differing letters (A, B, C) indicate significant differences among experimental groups over the three days (Fisher Protected Least Significant Difference Tests). Species and trophic groups: (a) Caenis robusta (mayfly nymph, 6-8 mm), scraper; (b) Asellus aquaticus (hog louse, 8-10 mm), shredder; (c) Ischnura elegans (damselfly nymph, 8-10 mm), predator; (d) Neomysis integer (opossum shrimp, 10-12 mm), predator; (e) Ischnura elegans (damselfly nymph, 15-20 mm), predator; ( $f$ ) Piscicola geometra (fish leech, 30-50 mm), parasite; ( $g$ ) Sigara sp. (waterboatman, 6-8 mm), herbivore shredder-piercer; (h) Eurycercus lamellatus (waterflea, 3-4 mm), filterer; (i) Chironomus sp. (midge larva, 12-14 mm), collector-gatherer; (j) Neomysis integer (opossum shrimp, 4-5 mm), predator; ( $k$ ) Chaoborus sp. (midge larva, 6-8 mm), predator.

(a)

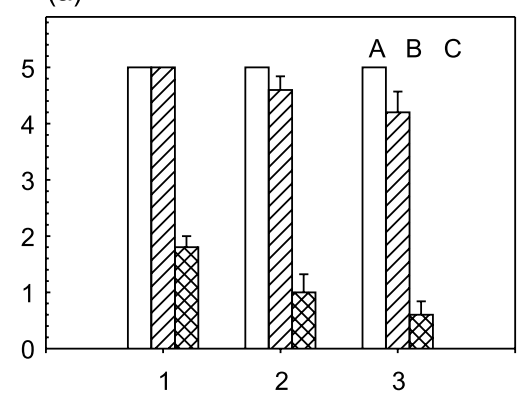

(d)

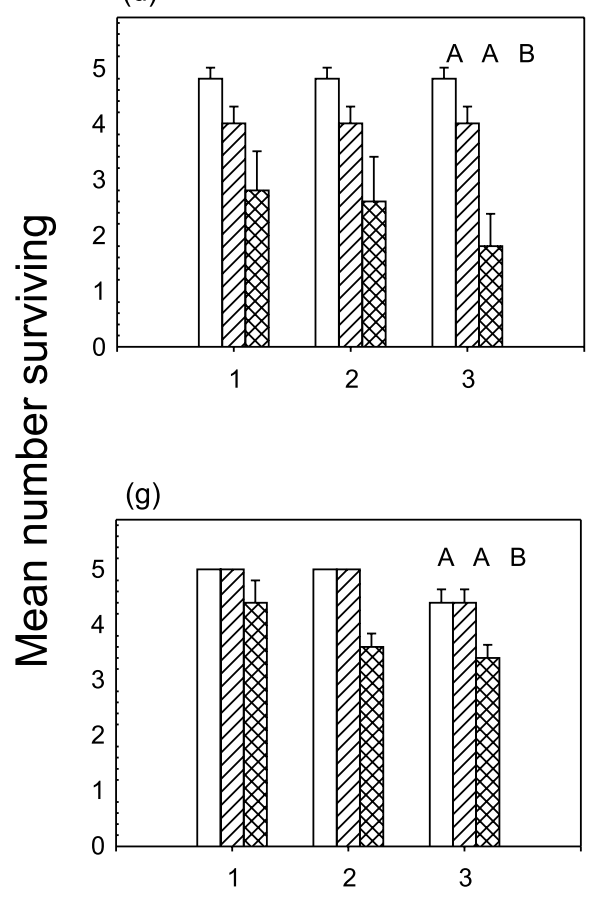

(j)

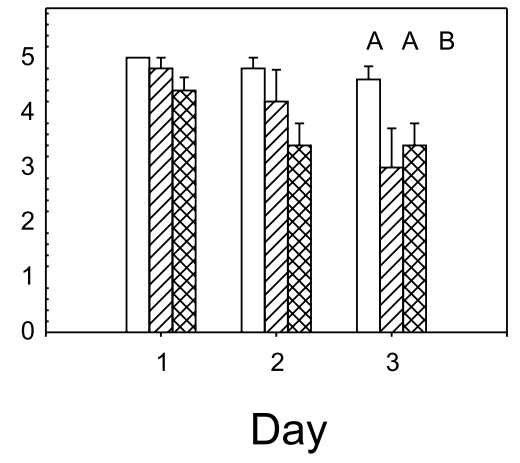

(b)

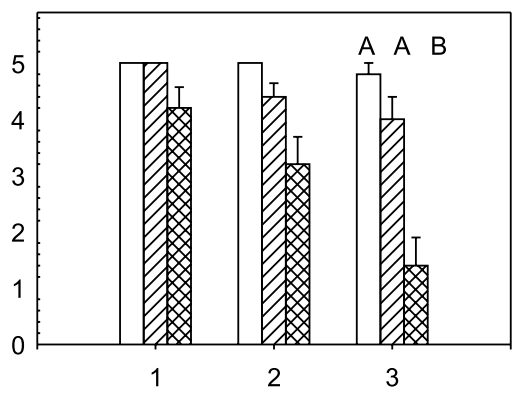

(e)

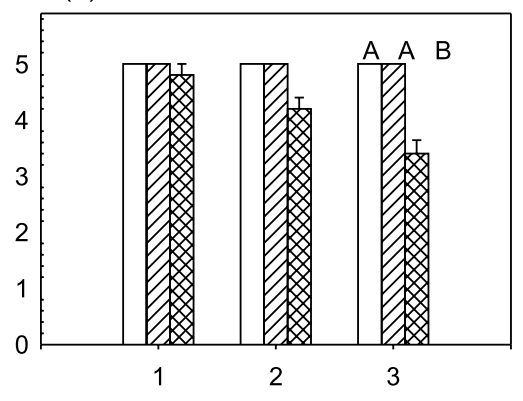

(h)

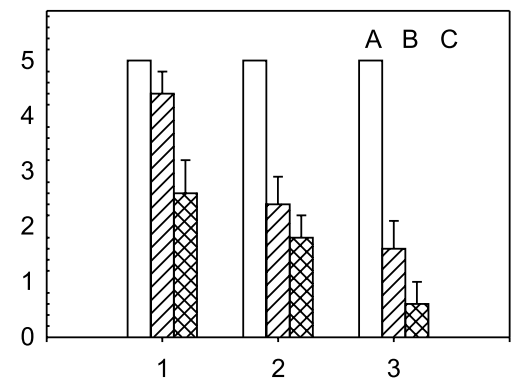

(k)

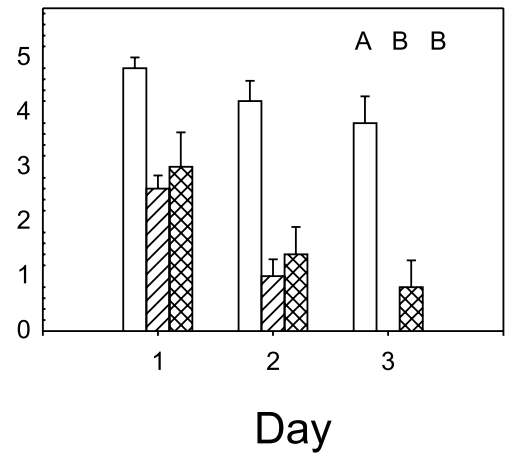

(c)
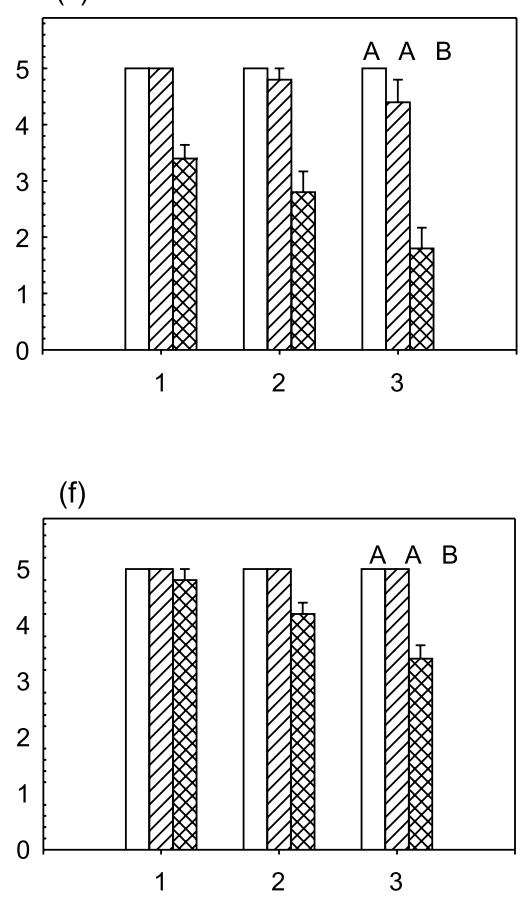

(i)

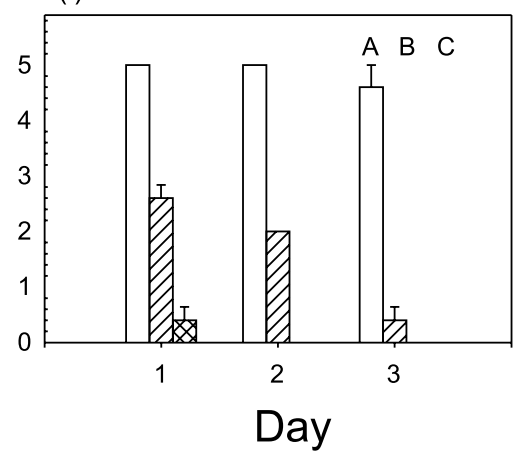


phipod present; (ii) a male G. duebeni present; (iii) a male D. villosus present. Twice daily (morning, evening), each replicate was inspected and the number and status (alive or dead) of amphipods and potential prey recorded. Any cadavers were removed and observed under binocular microscope for evidence of injury. Replicates were monitored for a further three days to examine, in groups (ii) and (iii), the survival of amphipods, thus giving an indication of their health under the laboratory conditions during the first three days, and similarly, replicates of group $(i)$ were monitored to indicate the health of the macroinvertebrates.

In Experiment 2, aquaria of $60 \times 40 \times 20 \mathrm{~cm}(\mathrm{~L} \times \mathrm{W} \times \mathrm{H})$ were supplied with $38.5 \mathrm{~L}$ of water and substrate as above. Each was supplied with five individuals of all 11 prey (see above) and 10 replicates monitored for three days in each of three experimental groups: (i) no amphipods; (ii) 11 male G. duebeni; (iii) 11 male D. villosus. Thus, amphipod-prey combinations and overall animal densities were as for microcosms, but scale was increased, amphipods had choice of prey, and all animals could interact with one another. The larger aquaria also reduced restrictions on potential distances that individuals could move vertically and horizontally. All replicates were inspected on day 3 .

For each macroinvertebrate prey, data for analyses were arcsine transformations (see Sokal and Rohlf 1995) of proportions surviving. Experiment 1 data were analyzed for each prey by two-factor ANOVA (analysis of variance), Factor 1 being amphipod status (none, G. duebeni, D. villosus) and Factor 2 being time (repeated measure; days 1, 2, 3). Post-hoc tests (Fisher Protected Least Significant Difference Tests) were used to examine differences among amphipod status groups. Experiment 2 data were analyzed by a onefactor MANOVA (multiple ANOVA), the factor being amphipod status (none, G. duebeni, D. villosus), and subsequently, survival of each individual prey species by onefactor ANOVA. (For clarity, the figures associated with these analyses show mean numbers surviving.)

\section{Results}

In Experiment 1, there were no deaths of amphipods in groups (ii) and (iii) by day 3 or even day 6 , indicating that the amphipod species were not differentially affected by laboratory conditions. The macroinvertebrates survived well in group (i) (i.e., no amphipods present) during the initial three days of the experiment (see Fig. 1), with no deaths over the subsequent three days. Thus, disappearances of macroinvertebrates in groups (ii) and (iii) could be reliably ascribed to amphipod predation of live individuals as opposed to scavenging following deaths due to some aspect of laboratory conditions. By day 3 of the experiment, and indeed mostly by day $1, D$. villosus significantly reduced survival of all 11 species - size classes of macroinvertebrate prey tested (Fig. 1; Table 1). In addition, D. villosus had a significantly greater and often more rapid impact on macroinvertebrate survival than $\operatorname{did} G$. duebeni for 10 of the 11 species - size classes and eight of the nine species tested (Fig. 1; Table 1). These differences in macroinvertebrate survival were clearly due to predation, with victims shredded and consumed. However, our observations also revealed predatory attacks that often left prey "bitten". Such individuals were removed from the microcosms, some photographed (see Fig. 2) and then isolated. Since all subsequently died within 1-3 h, these were classed as predatory kills in the data analyses.

Caenis robusta were shredded and eaten; however, we observed dead and dying specimens with bite damage to heads and bodies (Fig. 2). Indeed, in one replicate, all five nymphs sustained such bite injuries within $1.5 \mathrm{~h}$, all subsequently dying within $1 \mathrm{~h}$. We did not observe bite victims of $G$. duebeni, who shredded the nymphs they preyed upon. Asellus aquaticus and Ischnura elegans also suffered bite injuries (Fig. 2), the former even without having moulted and thus not yet being soft bodied. Neomysis integer (Leach) were killed more often in the larger than the smaller sizeclass, the latter appearing more capable of escape. Piscicola geometra appeared impervious to $G$. duebeni, but suffered significant predation and bite injuries by $D$. villosus. Sigara sp., despite being winged and hard-bodied, were preyed upon by D. villosus and often bitten (Fig. 2). Eurycercus lamellatus fell prey to both amphipods, but significantly more often, and generally more quickly, with $D$. villosus. Both amphipods preyed heavily on Chironomus sp. and Chaoborus sp.

In Experiment 2, two D. villosus and three G. duebeni replicates saw the death of one amphipod; however, this was considered negligible. There was a significant overall effect of "amphipod group" on the survival of macroinvertebrates $\left(F_{22,36}=2.3, P<0.01\right.$; Fig. 3$)$. Compared to the groups with no amphipods and $G$. duebeni present, $D$. villosus significantly reduced survival of $C$. robusta, A. aquaticus, I. elegans (both size classes), and Sigara sp. (Fig. 3; Table 1). Neomysis integer and $P$. geometra appeared unaffected by amphipods, whereas E. lamellatus, Chironomus sp., and Chaoborus sp. mostly disappeared. Mesocosms were characterized by the almost complete disappearance of victims, although we did observe predatory acts and injuries. For example, on four occasions I. elegans were observed being eaten alive by one or more D. villosus.

\section{Discussion}

Dikerogammarus villosus originates from an invasion donor "hot spot", the Ponto-Caspian region, with the ballast water of transoceanic shipping a likely invasion vector to the North American Great Lakes (see Mills et al. 1993; Ricciardi and Rasmussen 1998; Bruijs et al. 2001). Indeed, this species has already successfully invaded European regions like The Netherlands via new canals and shipping (Dick and Platvoet 2000; van der Velde et al. 2000). With many other invaders from the Ponto-Caspian established in the Great Lakes, this new invader may become part of a larger “invasional meltdown" (see Ricciardi and Rasmussen 1998; Simberloff and Von Holle 1999; Ricciardi 2001), particularly since zebra mussel (Dreissena polymorpha) beds, by providing substrate, may facilitate this large amphipod (see Stewart et al. 1998; Bially and MacIsaac 2000). Certainly, the arrival of D. villosus in western Europe has been concomitant with reductions in macroinvertebrate populations (see Introduction). Explanations and predictions of the ecological impact of $D$. villosus are therefore required, both as regards this specific case and to aid in the identification of future damaging invaders. 
Fig. 2. Victims of Dikerogammarus villosus often suffered head bites, but legs and bodies were also often damaged.
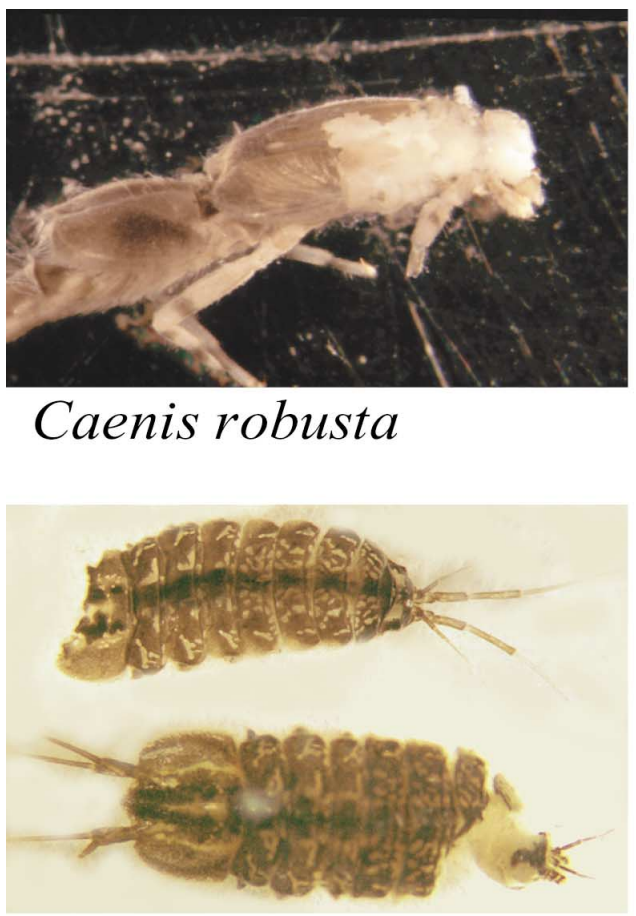

\section{Asellus aquaticus}
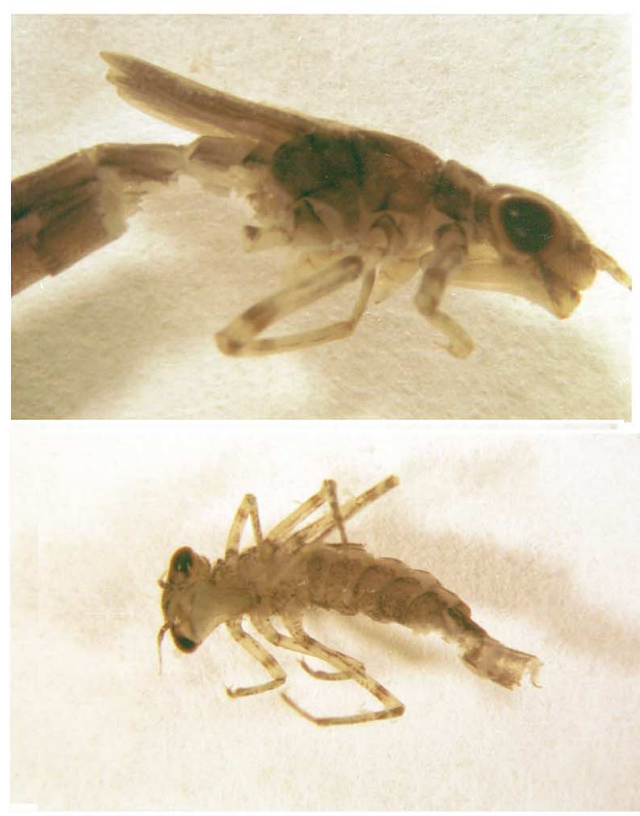

Ischnura elegans

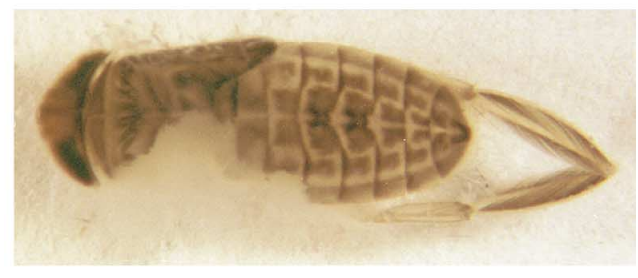

Sigara sp.
The two experiments presented here establish the exceptional predatory nature of $D$. villosus. Although animal material has been found in their guts (e.g., Hynes 1954; Ioffe 1973), amphipods such as D. villosus and G. duebeni have traditionally been viewed as principally herbivorous shredders and detritivores (Cummins and Klug 1979). More recently, however, this has been dispelled as a myth generated by over-reliance on the rigid Functional Feeding Group classification system (MacNeil et al. 1997). The predatory nature of such species concurs with the accumulated evidence of gut contents analyses, anecdotal accounts of prey capture and consumption, studies of cannibalism and intraguild predation, and most recently, demonstration of a variety of direct and indirect predatory effects of Gammarus spp. on macroinvertebrates (see Kelly et al. 2002). In addition, isotope analyses place $D$. villosus on the same trophic level as some fish species (Marguillier 1998). Microcosm and mesocosm studies have concurred with field surveys that predation by native Gammarus spp. significantly influences community composition (Anderson and Raasveldt 1974; Conlan 1994; Wilhelm and Schindler 1999). Thus, invasions into naïve communities by exotic amphipods with exceptional predatory capabilities may have profound impacts on biodiversity. Such scenarios may mirror species extinctions, both locally and globally, of naïve indigenous prey exposed to invading vertebrate predators (e.g., Zaret and Paine 1973; Diamond and Case 1986; Schoener and Spiller 1996).

Further, the present experimental approach has characterized the proximate behavioural interactions of $D$. villosus with a range of macroinvertebrate species that are likely to result during invasion. Thus, several taxonomic and trophic groups of a variety of body sizes, shapes, and structural strengths fell prey to D. villosus. In addition, in microcosms, D. villosus appeared to often simply attack and injure victims, indicating that impacts on prey may not be limited by predator satiation. On the other hand, such bite victims were not often observed at the mesocosm level, perhaps because of the increased likelihood of complete consumption of victims by multiple $D$. villosus and other predators-scavengers in the mesocosms. Whereas Experiment 1 indicates that D. villosus is capable of preying effectively on many such macroinvertebrate groups, Experiment 2 indicates that communities may experience differential impacts on prey species. This may arise through prey selection by $D$. villosus, since predators should take prey that is easy to catch and handle before taking more difficult prey. Indeed, species like $N$. integer, which have fast escape responses, were only significantly impacted by $D$. villosus in single-species scenarios, whereas the slow-moving A. aquaticus was impacted in both single- and mixed-species scenarios. Thus, D. villosus may switch to more difficult prey when easy prey are not present or have been depleted. In addition, declines in one species will have cascading effects on others, such that some species may increase following $D$. villosus invasion. For example, the loss of predators due to D. villosus, as occurred with I. elegans in the present study, may lessen their predatory impact and release prey species. Thus, currently and in the future, predation by $D$. villosus may have direct impacts on macroinvertebrate communities, reducing abundance and distributions of species, although indirect effects may include increases in populations of some species. Overall, a 
Fig. 3. Mean (+ standard error) survival of macroinvertebrates by day 3 in the mesocosm (multiple prey species) experiment, with no amphipod present (open bars), Gammarus duebeni present (hatched bars), and Dikerogammarus villosus present (cross-hatched bars). Differing letters (A,B,C) indicate significant differences among experimental groups at day 3. Cr, Caenis robusta; Aa, Asellus aquaticus; Ie(s), Ischnura elegans (small); Ni(1), Neomysis integer (large); Ie(1), Ischnura elegans (large); Pg, Piscicola geometra; S, Sigara sp; El, Eurycercus lamellatus; Chi, Chironomus sp; Ni(s), Neomysis integer (small); Cha, Chaoborus sp.

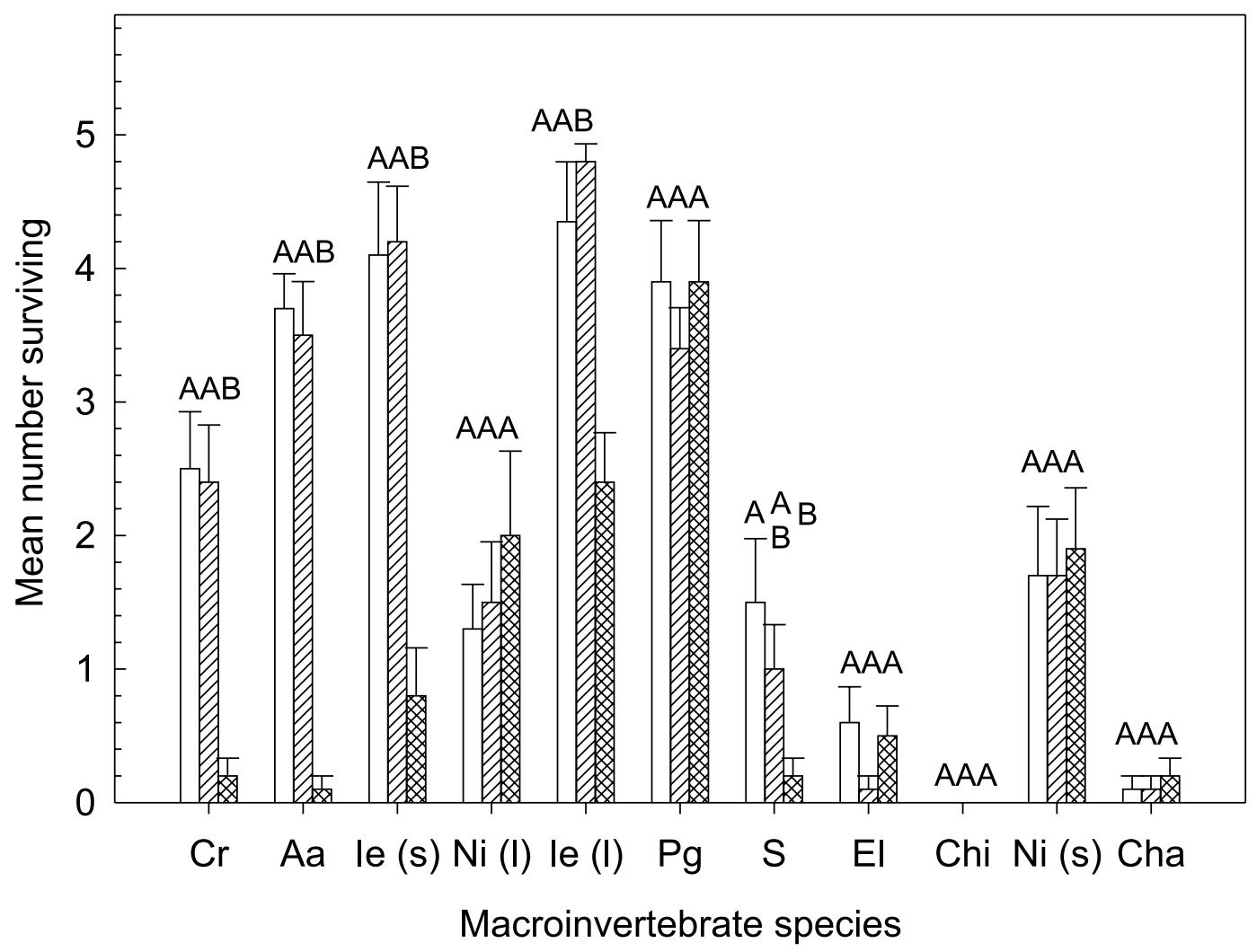

simplification of macroinvertebrate communities, in terms of species and trophic links, appears likely, a pattern that is emerging in the River Rhine (see van der Velde et al. 2000). This is a feature of other systems invaded by exceptional predators (e.g., Zaret and Paine 1973). Further, energy flow in invaded systems may be disrupted, such that higher trophic groups are affected. However, these aspects may only be addressed by monitoring pre- and post- $D$. villosus invasions in the field.

Although we used the same animal densities in our microcosm and mesocosm scales, larger experimental arenas have reduced edge effects, such that prey have more opportunity of escape from a particular predator and encounter rates may be reduced (see also Wilhelm et al. 2000). However, both of our experimental scales showed significant predation of macroinvertebrates in short time periods. This concurs with other studies whereby amphipod predation at small and intermediate laboratory scales, albeit of higher magnitude, has been shown to agree with large field scale enclosures and wholelake patterns (Dick et al. 1999; Wilhelm and Schindler 1999; Wilhelm et al. 2000). In addition, the present experiments show that predation by the invader $D$. villosus is significantly greater than that of a native counterpart, G. duebeni. Thus, although laboratory enclosures may overestimate rates of predation in field situations, the relative predatory impact of $D$. villosus may be predicted to be profound in comparison to native counterparts, which themselves are likely to be replaced through predation by $D$. villosus (see Dick and Platvoet 2000).

With freshwater biodiversity over the next 100 years judged to be most influenced by species invasions (Sala et al. 2000), it is imperative that research focuses on explanations and predictions of the identities and impacts of new invaders. Such efforts must be both field and laboratory based, such that invasion patterns and the mechanisms of impacts can be linked. Such information may then be used in aquatic resource management strategies, such as the prevention and control of potentially damaging future invasions. In the present case, the clearly invasive nature of $D$. villosus and its impacts in freshwaters in Europe, in addition to its demonstrated predatory abilities, indicate this to be one such undesirable future invader.

\section{Acknowledgements}

We thank the British Council for initial financial support through their U.K.-Dutch Joint Scientific Research Programme. The University of Amsterdam also kindly provided two small research grants and David Kelly acknowledges funding from Department of Higher and Further Education, Training and Employment (DHFETE). We are grateful to Fred Schram, Rob van Soest, Ian Montgomery, Bob Elwood, Roberta Bailey, Calum MacNeil, and Ivan Ewart for a variety of helpful input. 


\section{References}

Anderson, R.S., and Raasveldt, L.G. 1974. Gammarus predation and the possible effects of Gammarus and Chaoborus feeding on the zooplankton composition in some small lakes and ponds in western Canada. Can. Wildl. Serv. Occas. Pap. 18: 1-23.

Bially, A., and MacIsaac, H.J. 2000. Fouling mussels (Dreissena spp.) colonize soft sediments in Lake Erie and facilitate benthic invertebrates. Freshwater Biol. 43: 85-97.

Bruijs, M.C.M., Kelleher, B., van der Velde, G., and bij de Vaate, A. 2001. Oxygen consumption, temperature and salinity tolerance of the invasive amphipod Dikerogammarus villosus: indicators of further dispersal via ballast water transport. Arch. Hydrobiol. 152: 633-646.

Conlan, K.E. 1994. Amphipod crustaceans and environmental disturbance: a review. J. Nat. Hist. 28: 519-554.

Cummins, K.W., and Klug, M.J. 1979. Feeding ecology of stream invertebrates. Annu. Rev. Ecol. Syst. 10: 147-172.

Devin, S., Beisel, J.N., Bachman, V., and Moreteau, J.C. 2001. Dikerogammarus villosus (Amphipoda: Gammaridae): another invasive species newly established in the Moselle river and French hydrosystems. Ann. Limnol. 37: 21-27.

Diamond, J., and Case, T.J. 1986. Overview: introductions, extinctions, exterminations, and invasions. In Community ecology. Edited by J. Diamond and T.J. Case. Harper and Row, New York. pp. 65-79.

Dick, J.T.A., and Platvoet, D. 2000. Invading predatory crustacean Dikerogammarus villosus eliminates both native and exotic species. Proc. R. Soc. Lond. Ser. B Biol. Sci. 267: 977-983.

Dick J.T.A., Montgomery, W.I., and Elwood, R.W. 1999. Intraguild predation may explain an amphipod replacement; evidence from laboratory populations. J. Zool. (London), 249: 463-468.

Hall, S.R., and Mills, E.L. 2000. Exotic species in large lakes of the world. Aquat. Ecosyst. Health Manage. 3: 105-135.

Holway, D.A., and Suarez, A.V. 1999. Animal behavior: an essential component of invasion biology. Trends Ecol. Evol. 14: 328-330.

Huston, M.A. 1999. Microcosm experiments have limited relevance for community and ecosystem ecology: synthesis of comments. Ecology, 80: 1088-1089.

Hynes, H.B.N. 1954. The ecology of Gammarus duebeni Lilljeborg and its occurrence in freshwater in western Britain. J. Anim. Ecol. 23: 38-84.

Ioffe, I.I. 1973. Pool for acclimatization of invertebrates in U.S.S.R. Izv. Gos. Nauchno-Issled. Inst. Ozern. Rechn. Rybn. Khoz. 84: $18-68$.

Kelly, D.W., Dick, J.T.A., and Montgomery, W.I. 2002. Predation on mayfly nymph, Baetis rhodani, by native and introduced Gammarus: direct effects and the facilitation of salmonid predation. Freshwater Biol. 47: 1257-1268.

Mack, R.N., Simberloff, D., Lonsdale, W.M., Evans, H., Clout, M., and Bazzaz, F.A. 2000. Biotic invasions: causes, epidemiology, global consequences, and control. Ecol. Appl. 10: 689-710.

MacNeil, C., Dick, J.T.A., and Elwood, R.W. 1997. The trophic ecology of freshwater Gammarus (Crustacea: Amphipoda); problems and perspectives concerning the Functional Feeding Group concept. Biol. Rev. (Cambridge), 72: 349-364.

Marguillier, S. 1998. Stable isotope ratios and food web structure of aquatic ecosystems. Thesis, Universiteit Brussel.
Mills, E.L., Leach, J.H., Carlton, J.T., and Secor, C.L. 1993. Exotic species in the Great Lakes: a history of biotic crises and anthropogenic introductions. J. Gt. Lakes Res. 19: 1-54.

Musko, I. 1993. The life history of Dikerogammarus haemobaphes (EICHW.) (Crustacea; Amphipoda) living on macrophytes in Lake Balaton (Hungary). Arch. Hydrobiol. 127: 227-238.

Peckarsky, B.L., Cooper, S.D., and McIntosh, A.R. 1997. Extrapolating from individual behaviour to populations and communities in streams. J. North Am. Benthol. Soc. 16: 375-390.

Ricciardi, A. 2001. Facilitative interactions among aquatic invaders: is an "invasional meltdown" occurring in the Great Lakes? Can. J. Fish. Aquat. Sci. 58: 2513-2525.

Ricciardi, A., and MacIsaac, H.J. 2000. Recent mass invasion of the North American Great Lakes by Ponto-Caspian species. Trends Ecol. Evol. 15: 62-65.

Ricciardi, A., and Rasmussen, J.B. 1998. Predicting the identity and impact of future biological invaders: a priority for aquatic resource management. Can. J. Fish. Aquat. Sci. 55: 1759-1765.

Sala, O.E., Chapin, F.S., Armesto, J.J., Berlow, E., Bloomfield, J., Dirzo, R., Huber-Sanwald, E., Huenneke, L.F., Jackson, R.B., Kinzig, A., Leemans, R., Lodge, D.M., Mooney, H.A., Oesterheld, M., Poff, N.L., Sykes, M.T., Walker, B.H., Walker, M., and Wall, D.H. 2000. Global biodiversity scenarios for the year 2100. Science (Washington, D.C.), 287: 1770-1774.

Schoener, T.W., and Spiller, D.A. 1996. Devastation of prey diversity by experimentally introduced predators in the field. Nature (London), 381: 691-694.

Simberloff, D., and Von Holle, B. 1999. Positive interactions of nonindigenous species: invasional meltdown? Biol. Invasions, 1: 21-32.

Sokal, R.R., and Rohlf, F.J. 1995. Biometry. The principles and practice of statistics in biological research. 3rd ed. W.H. Freeman, New York.

Stewart, T.W., Miner, J.G., and Lowe, R.L. 1998. Macroinvertebrate communities on hard substrates in western lake Erie: structuring effects of Dreissena. J. Gt. Lakes Res. 24: 868-879.

van der Velde, G., Rajagopal, S., Kelleher, B., Musko, I.B, and bij de Vaate, A. 2000. Ecological impact of crustacean invaders: general considerations and examples from the Rhine River. In The biodiversity crisis and Crustacea. Proceedings of the Fourth International Crustacean Congress. Edited by J.C. von Vaupel Klein, and F.R. Schram. Balkema, Rotterdam, The Netherlands. Crustac. Issues. Vol. 12. pp. 3-33.

Welton, J.S. 1979. Life-history and production of the amphipod Gammarus pulex in a Dorset chalk stream. Freshwater Biol. 9: 263-275.

Wilhelm, F.M., and Schindler, D.W. 1999. Effects of Gammarus lacustris (Crustacea: Amphipoda) on plankton community structure in an alpine lake. Can. J. Fish. Aquat. Sci. 56: 1401-1408.

Wilhelm, F.M., Schindler, D.W., and McNaught, A.S. 2000. The influence of experimental scale on estimating the predation rate of Gammarus lacustris (Crustacea: Amphipoda) on Daphnia in an alpine lake. J. Plankton Res. 22: 1719-1734.

Zaret, T.M., and Paine, R.T. 1973. Species introductions in a tropical lake. Science (Washington, D.C.), 182: 449-455. 